\title{
Peran Aktif Masyarakat Hukum Adat Dalam Pembangunan Ekonomi
}

\author{
Jenni Kristiana Matuankotta \\ Fakultas Hukum Universitas Pattimura, Ambon, Indonesia \\ E-mail:jkmatuankotta@gmail.com
}

\begin{abstract}
The active role of the customary law community in the process of economic development is very large supported by abundant natural wealth spread across the archipelago. This considerable potential will be better and can be supported by reliable human resources. Customary law communities can be included to participate in economic development. Empowerment of indigenous peoples with their local knowledge through economic development based on local wisdom can provide support, use and management of natural resources while maintaining the strength of their customary law, their spiritual abilities and the beliefs they embrace.
\end{abstract}

Keywords: Active Role of Customary Law Community, Local Wisdom

\section{A. PENDAHULUAN.}

Sejak Indonesia berdiri sebagai negara berdaulat, hukum adat menempati perannya sendiri dan dalam perkembangannya, hukum adat justru mendapat tempat khusus dalam pembangunan hukum nasional. Dalam pembentukan hukum negara pun, kebiasaan-kebiasaan (sering disebut kearifan lokal) yang hidup dalam masyarakat menjadi salah satu pertimbangan penting dalam pembentukan hukum negara, baik pada pembentukan undang-undang maupun dalam pembentukan peraturan daerah. Konsep pluralisme hukum tidak lagi tidak berkembang dalam ranah dikotomi antara sistem hukum negara (state law) di satu sisi dengan sistem hukum rakyat (folk law) dan hukum agama (religious law) di sisi yang lain. Pada tahap perkembangan ini, konsep pluralisme hukum lebih menekankan pada interaksi dan ko-eksistensi berbagai sistem hukum yang mempengaruhi bekerjanya norma, proses, dan institusi hukum dalam masyarakat.

Hukum menjadi salah satu produk kebudayaan yang tak terpisahkan dengan segi-segi kebudayaan yang lain, seperti politik, ekonomi, struktur dan organisasi sosial, ideologi, religi, dan lain-lain. Untuk memperlihatkan perkembangan pemikiran konsep pluralisme hukum keterpautan hukum dengan aspek-aspek kebudayaan yang lain, maka menarik untuk mengungkapkan teori hukum 
sebagai suatu sistem (the legal system) seperti berikut ${ }^{1}$ :

Hukum sebagai suatu sistem pada pokoknya mempunyai 3 elemen, yaitu :

a) Struktur sistem hukum (structure of legal system) yang terdiri dari lembaga pembuat undang-undang (legislatif), institusi pengadilan dengan strukturnya, lembaga kejaksaan dengan strukturnya, badan kepolisian negara, yang berfungsi sebagai aparat penegak hukum;

b) Substansi sistem hukum (substance of legal system) yang berupa norma-norma hukum, peraturan-peraturan hukum, termasuk pola-pola perilaku masyarakat yang berada dibalik sistem hukum; dan

c) Budaya hukum masyarakat (legal culture) seperti nilai-nilai, ide-ide, harapan-harapan dan kepercayaan-kepercayaan yang terwujud dalam perilaku masyarakat dalam mempresepsikan hukum.

Undang-Undang Nomor 6 Tahun 2014 tentang Desa menempatkan Lembaga Adat Desa sebagai lembaga yang menyelenggarakan fungsi adat istiadat dan menjadi bagian dari susunan asli desa yang tumbuh dan berkembang atas prakarsa masyarakat desa. Keberadaan Lembaga Adat di desa dalam hal ini tidak otomatis menyebabkan desa berubah status menjadi desa adat. Ketentuan khusus sebagaimana ditur dalam Undang-undang Desa menjelaskan bahwa Desa Adat harus memenuhi persyaratan sebagai kesatuan masyarakat hukum adat beserta hak tradisionalnya yang secara nyata masih hidup dengan ikatan teritorial atau genealogis maupun fungsional. Sebagai kesatuan masyarakat hukum adat, desa adat memenuhi unsur :

1 Friedman, Lawrence M. (1977). Law and Society An Introduction, New Jersey: Prentice Hall Inc, h. 6-7
1) Wilayah/ulayat adat;

2) Kelompok warga masyarakat dengan ikatan perasaan bersama;

3) Memiliki pranata pemerintahan adat;

4) Memiliki kekayaan dan atau benda adat;

5) Perangkat norma hukum adat beserta hak tradisionalnya masih berkembang dan sesuai dengan prinsip NKRI.

Berbeda dengan Desa Adat, Lembaga Adat Desa merupakan organisasi yang berkedudukan sebagai lembaga kemasyarakatan yang menjadi mitra Pemerintah Desa dalam memberdayakan, melestarikan dan mengembangkan adat istiadat lokal yang menunjang penyelenggaraan pemerintahan, kemasyarakatan dan pembangunan. Keberadaan Lembaga Adat Desa juga berfungsi mengayomi juga melestarikan nilai, sistem sosial maupun benda material dari kebudayaan lokal.

Pemberdayaan dimaksudkan untuk memperkokoh fungsi dan peran Lembaga Adat Desa sebagai wadah sekaligus fasilitator pengelolaan pembangunan desa dengan acuan nilai, norma, tradisi, budaya dan kearifan lokal. Pelestarian dimaksudkan untuk menjaga agar nilai, adat-istiadat dan kebiasaan yang telah tumbuh, hidup dan berkembang dalam praktis kultural, tetap lestari dan tidak hilang. Nilai, tradisi, adat istiadat, budaya yang tumbuh pada suatu masyarakat pada dasarnya juga menjadi asset atau modal sosial yang penting dalam rangka memberdayakan (empowering) masyarakat demi mewujudkan kualitas hidup dan kesejahteraan.

Paradigma pemahaman hukum adat dan perkembangannya harus diletakkan pada ruang yang besar, dengan mengkaji secara luas :

1) Kajian yang tidak lagi melihat sistem hukum suatu negara berupa hukum negara, namun juga 
hukum adat, hukum agama serta hukum kebiasaan;

2) Pemahaman hukum (adat) tidak hanya memahami hukum adat yang berada dalam komunitas tradisional masyarakat pedesaan, tetapi juga hukum yang berlaku dalam lingkungan masyarakat tertentu (hybrid law atau unnamed law);

3) Memahami gejala trans nasional law sebagaimana hukum yang dibuat oleh organisasi multilateral, maka adanya hubungan interdependensi antara hukum internasional, hukum nasional dan hukum lokal.

Studi hukum adat dalam perkembangan mengkaji hukum adat sepanjang perkembangannya di dalam masyarakat, dilakukan secara kritis obyektif analistis, artinya hukum adat akan dikaji secara positif dan secara negatif. Secara positif artinya hukum adat dilihat sebagai hukum yang bersumber dari alam pikiran dan cita-cita masyarakatnya. Secara negatif hukum adat dilihat dari luar, dari hubungannya dengan hukum lain baik yang menguatkan maupun yang melemahkan dan interaksi perkembangan politik kenegaraan.

Hukum adat sebagai hukum yang dibangun berdasarkan paradigma atau nilai-nilai : harmoni, keselarasan, keutuhan menentukan corak, sifat, karakter hukum adat. Kluckhon mengemukakan: nilai merupakan " $a$ conception of desirable" (suatu konsepsi yang diinginkan). Maka nilai ada beberapa tingkatan, yaitu :

1) Nilai Primer merupakan nilai pegangan hidup bagi suatu masyarakat, bersifat abstrak dan tetap seperti: kejujuran, keadilan, keluhuran budi, kebersamaan dan lain-lain.,

2) Nilai subsider berkenaan dengan kegunaan, karena itu lebih berbicara hal-hal yang bersifat konkrit. Maka hukum lebih banyak ditujukan pada nilai-nilai sekunder yaitu nilai-nilai yang berguna untuk memecahkan persoalan konkrit yang sedang dihadapi masyarakat, atau orang-perorangan. Timbulnya nilai sekunder tersebut, telah melalui penyaringan (sannering) oleh nilai-nilai primer. Nilai sekunder bisa berubah menyesuaikan dengan kebutuhan dan perkembangan dan menjawab persoalan yang ada dalam masyarakat. Hukum termasuk hukum adat sesungguhnya juga didasarkan pada nilai primer, namun pendasaran pada nilai sekunder, sifatnya lebih nyata dan dipahami. ${ }^{2}$

Soepomo mengatakan: Corak atau pola-pola tertentu di dalam hukum adat yang merupakan perwujudan dari struktur kejiwaan dan cara berfikir yang tertentu oleh karena itu unsur-unsur hukum adat adalah :

1) Mempunyai sifat kebersamaan yang kuat artinya manusia menurut hukum adat merupakan makluk dalam ikatan kemasyarakatan yang erat, rasa kebersamaan meliputi sebuah lapangan hukum adat;

2) Mempunyai corak magisch-religius, yang berhubungan dengan pandangan hidup;

3) Sistem hukum itu diliputi oleh pikiran serba kongkrit, artinya hukum adat sangat memperhatikan banyaknya dan berulang-ulangnya hubungan-hubungan hidup yang kongkrit. Sistem hukum adat mempergunakan

2 Soepomo , Bab-Bab Tentang Hukum Adat. Jakarta: Pradnya Paramita, h. 30. 
hubungan-hubungan yang kongkrit tadi dalam pergaulan hidup;

4) Hukum adat mempunyai sifat visual artinya hubungan-hubungan hukum dianggap hanya terjadi oleh karena ditetapkan dengan suatu ikatan yang dapat dilihat (atau tanda yang tampak).

Menurut Moch Koesnoe mengemukakan corak hukum adat ${ }^{3}$ :

1) Segala bentuk rumusan adat yang berupa kata-kata adalah suatu kiasan saja. Menjadi tugas kalangan yang menjalankan hukum adat untuk banyak mempunyai pengetahuan dan pengalaman agar mengetahui berbagai kemungkinan arti kiasan dimaksud;

2) Syarat sebagai keseluruhan selalu menjadi pokok perhatiannya. Artinya dalam hukum adat kehidupan manusia selalu dilihat dalam wujud kelompok, sebagai satu kesatuan yang utuh;

3) Hukum adat lebih mengutamakan bekerja dengan asas-asas pokok. Artinya dalam lembaga-lembaga hukum adat diisi menurut tuntutan waktu tempat dan keadaan serta segalanya diukur dengan asas pokok, yakni kerukunan, kepatutan dan keselarasan dalam hidup bersama.

Pembangunan sebagai suatu proses pada hakikatnya merupakan pembaharuan yang terencana dan dilaksanakan dalam tempo yang relatif cepat. Tidak dapat dipungkiri pembangunan telah membawa kita pada kemajuan ilmu pengetahuan dan

3 Koesnoe, Moch.(2000). Prinsip-prinsip Hukum Adat tentang Tanah, Surabaya: Ubhara Press, h.136 teknologi, pertumbuhan ekonomi, peningkatan kecanggihan sarana komunikasi dan sebagainya. Akan tetapi, pada sisi yang lain, pembangunan yang hanya dipadu oleh pertimbangan-pertimbangan ekonomi dan keamanan, yang dalam kenyataannya telah meningkatkan kesejahteraan sebagian dari keseluruhan kehidupan masyarakat, telah pula menciptaka jarak yang lebar antara kecanggihan dan keterbelakangan.

Kebudayaan dan kearifan lokal sangat erat hubungannya dengan masyarakat, maknanya bahwa segala sesuatu yang terdapat dalam masyarakat dipengaruhi oleh kebudayaan yang dimiliki oleh masyarakat itu sendiri. Kebudayaan dapat dipandang sebagai sesuatu yang turun-temurun dari satu generasi ke generasi yang lain, yang kemudian disebut sebagai superorganic.

Kearifan lokal merupakan suatu kelembagaan informal yang mengatur hubungan atas pengolahan sumber daya di suatu masyarakat. Hal ini dapat diuraikan bahwa tradisi (invented tradition) sebagai seperangkat aksi atau tindakan yang biasanya ditentukan oleh aturan-aturan yang dapat diterima secara jelas atau samar-samar maupun suatu ritual atau sifat simbolik, yang ingin menanamkan nilai-nilai dan norma-norma perilaku tertentu melalui pengulangan, yang secara otomatis mengimplikasikan adanya kesinambungan dengan masa lalu. Salah satu contoh yakni masyarakat di Kepulauan Aru merupakan masyarakat yang memiliki peradaban ekosentrisme, hal ini tercermin dalam pemanfaatan sumber daya pesisir dan laut sebagai mata pencaharian utamanya yang dibarengi dengan pengetahuan dan kearifan lokal tentang pengetahuan ekosistem pesisir dan kepulauan.

Pada bulan Mei-Oktober, atau yang dikenal dengan Musim Timur orang-orang Aru biasanya akan bekerja di kebun-kebun dan membuat kanji 
berbahan sagu, mereka juga dapat berburu rusa dan babi hutan di daerah savana dan hutan-hutan serta dapat mengumpulkan beberapa jenis moluska, kepiting dan teripang di sekitar pantai. Sedangkan pada bulan November-April atau Musim Barat, masyarakat Aru sepenuhnya akan terfokus untuk mencari dan memanfaatkan sumber daya dari laut. Dalam hubungannya dengan kepercayaan terhadap leluhur, masyarakat Aru masih sangat memegang kuat apa yang diajarkan leluhur pada mereka. Terutama hubungan manusia dengan alam, kepercayaan-kepercayaan yang mereka anut merupakan instrumen tangguh dalam menjaga keharmonisan hubungan manusia dengan alam. Masyarakat Aru percaya alam dengan seluruh isinya adalah "milik para leluhur" yang senantiasa mengawasi mereka. Dengan pandangan seperti ini, keseimbangan yang secara alami terkandung di alam akan selalu terjaga, karena hal-hal yang merusak seperti eksploitasi yang berlebihan dan yang lainnya dapat terhindar oleh karena adanya kepercayaan bahwa manusia tidak memiliki hak untuk alamnya selain untuk kebutuhan dasar hidupnya.

Sebagai mediator, masyarakat Aru memiliki Kepala Adat untuk melakukan dialog antara leluhur dengan anak-cucunya. Karena itu setiap akan melakukan kegiatan, didahului dengan upacara dialog. Hasil dialog tersebut berupa kesepakatan-kesepakatan yang harus ditaati, misalnya dalam hal berburu teripang, ada jenis-jenis tertentu yang hanya boleh diambil pada saat-saat tertentu saja, hanya boleh mengambil teripang yang berukuran besar saja, dan ada masa larangan untuk mengambil teripang dan sebagainya. Hal ini mengandung pengertian untuk memberi kesempatan alam melakukan regenerasi. Leluhur, sebagai pemilik alam raya akan murka bila kesepakatannya dilanggar, hal tersebut dimanifestasikan dalam bentuk bencana alam, dijumpai adanya sistem pengelolaan sumber daya alam secara tradisional.

Diantara fenomena atau wujud kearifan lokal, yang merupakan bagian inti kebudayaan adalah nilai-nilai dan konsep-konsep dasar yang memberikan arah bagi berbagai tindakan. Menggali dan menanamkan kembali kaerifan lokal secara interen dapat dikatakan sebagai gerakan kembali pada basis nilai budaya daerahnya sendiri sebagai bagian upaya membangun identitas suatu daerah, yang memiliki korelasi menciptakan langkah-langkah strategis dan nyata dalam memberdayakan dan mengembangkan potensi (sosial, budaya, ekonomi, politik dan keamanan) daerah secara optimal serta sebagai filter dalam menyeleksi berbagai pengaruh budaya dari luar.

Kearifan lokal merupakan kekuasaan dan potensi riil yang dimiliki suatu daerah sebagai aset daerah yang mendorong pengembangan dan pembangunan daerah. Selanjutnya dalam usaha membangun daerah perlu dilakukan pemberdayaan budaya lokal dan kearifan lokal yang mendukung penyusunan strategi budaya atau rumusan rencana kegiatan budaya di daerah sebagai landasan daerah di bidang budaya. kearifan lokal sebagai strategi utama dalam perbaikan ekonomi di masa depan khususnya ekonomi berkelanjutan sangatlah tepat. Dikarenakan mayarakat dapat mengetahui lebih jauh apa yang harus dilakukan dan dibutuhkan dalam melakukan kegiatan ekonomi sesuai dengan potensi yang dimiliki suatu daerah.

Budaya meliputi semua peneguhan perilaku yang diterima selama satu periode kehidupan, budaa juga berkenaan dengan bentuk dan struktur fisik serta lingkungan sosial yang mempengaruhi kehidupan masyarakat, ${ }^{4}$ adat istiadat merupakan kehidupan bertatakrama yang

4 Mubarak dan Hasyim, (2008). Buku Ajar II Manusia, Akhlak, Budi Pekerti dan Masyarakat, Universitas Indonesia, h. 42-43. 
dilindungi oleh hukum dan peraturan yang berlaku ditengah-tengah masyarakat.

Salah satu contoh sederhana nilai kearifan lokal bangsa Indonesia dari sisi budaya yang telah dimiliki dan dikembangkan sejak dulu hingga sekarang adalah budaya gotong royong. Budaya ini, mengandung nilai-nilai kebersamaan dan kekeluargaan dengan gotong royong, suatu pelaksanaan kegiatan dapat terselesaikan dengan efektif dan efisien, maka dari budaya gotong royong kerap disebut sebagai budaya nasional.

Berdasarkan uraian di atas, maka yang menjadi isu permasalahan pada problemtika dalam peran aktif masyarakat hukum adat dalam pembangunan ekonomi yakni bagaimana upaya pemberdayaan masyarakat dalam pembangunan ekonomi yang berbasis kearifan lokal ?

\section{B. PEMBAHASAN}

\section{Pembangunan Ekonomi Berbasis Kearifan Lokal.}

Aspek ekonomi merupakan hal yang sangat menunjang majunya suatu bangsa. Aspek ekonomi merupakan aspek adaptasi yang mana pembangunan ekonomi bangsa sangat barkaitaan dengan pola regulasi hukum yang benar sehingga dalam pelaksanaannya akan tercipta pembangunan yang ideal sebagaimana tertuang dalam Pasal 33 UUD 1945, bahwa :

"Perekonomian disusun sebagai usaha bersama berdasar asas kekeluargaan. Cabang-cabang produksi yang penting bagi Negara dan menguasai hajat hidup orang banyak dikuasai oleh Negara. Bumi dan air dan kekayaan alam yang terkandung didalamnya dikuasai oleh Negara dan dipergunakan untuk sebesar - besarnya kemakmuran rakyat".
Jika demikian halnya di atas maka dibutuhkan pola regulasi hukum yang sinkron dan dapat mengatur secara spesifik perekonomian Indonesia sebagai wujud pembangunan ekonomi kerakyatan sehingga tidak tumpang tindih kebijakan yang dilahirkan. Hukum dan Pembangunan merupakan terjemahan dari Law and Development, yang mulai berkembang di Amerika Serikat sesudah perang dunia kedua. Jika merunut pada pengertian yang dikembangkan di Amerika khususnya yang berhubungan dengan organisasi United States Agency for Interantional Development (USAID) dan lembaga seperti Ford Foundation atau Rockefeller Foundation, maka perkembangan hukum dan pembangunan dapat dibaca dari upaya lembaga-lembaga ini dalam mempengaruhi dan memperkenalkan kepada negara-negara berkembang dalam melakukan pembangunan ekonomi dan pembangunan infrastruktur. Hal ini dimulai dengan melakukan pengiriman dan reseach oleh ahli hukum dari Amerika. Bahkan pada tahun 1966 Kongres Amerika mengundangkan "Foreign Asistence Act of" untuk membantu Negara-negara berkembang di Asia, Afrika dan Amerika Latin memperbaharui dan memperkuat system hukum. Pengiriman para ahli hukum Amerika ini merupakan bagian yang tak terpisahkan dari agenda bantuan. Hal ini dapat dilihat secara nyata dari besarnya bantuan keuangan yang dianggarkan, dimana untuk Afrika misalnya diperkirakan sebesar US \$ 15 juta dan sebesar US \$ 5 juta. Biaya yang besar ini dikeluarkan karena ada anggapan bahwa modernisasi hukum pada negara-negara yang baru itu sangat diperlukan dan hukum yang modern itu diperlukan untuk mempromosikan pembangunan ekonomi. Hal di atas didasari oleh pemikiran bahwa hukum yang modern itu akan memberi pengaruh pada pembangunan ekonomi, karena hukum yang modern itu 
memberikan fasilitas dan ruang pada perencanaan ekonomi sebab hukum yang modern itu sebagai sarana yang tepat untuk membangun masyarakat. Rasio dari perlunya hukum yang modern dalam pembangunan karena pada hukum modern mempunyai ciri-ciri antara lain:

1) Aturan diterapkan dengan cara yang tidak berbeda

2) Perundang-undangan bersifat transaksional

3) Norma hukum modern bersifat universal

4) Sistem hukum bersifat hirarkis

5) Sistem hukum diatur secara birokratis

6) Sistem hukum bersifat rasional

7) Sistem hukum dijalankan oleh para ahli hukum

8) Sistem hukum bersifat tehnis dan komplek

9) Sistem hukum dapat diubah

10) Sistem ini bersifat politik dan

11) Tugas membuat dan menerapkan undang dilakukan oleh pihak yang berbeda.

Hukum dan Pembangunan merupakan terjemahan dari Law and Development, yang mulai berkembang di Amerika Serikat sesudah perang dunia kedua. Jika merunut pada pengertian yang dikembangkan di Amerika khususnya yang berhubungan dengan organisasi United States Agency for Interantional Development (USAID) dan lembaga seperti Ford Foundation atau Rockefeller Foundation, maka perkembangan hukum dan pembangunan dapat dibaca dari upaya lembaga-lembaga ini dalam mempengaruhi dan memperkenalkan kepada negara-negara berkembang dalam melakukan pembangunan ekonomi dan pembangunan infrastruktur.

Hal ini dimulai dengan melakukan pengiriman dan reseach oleh ahli hukum dari Amerika. Bahkan pada tahun 1966 Kongres Amerika mengundangkan "Foreign Asistence Act of 1966" untuk membantu Negara-negara berkembang di Asia, Afrika dan Amerika Latin memperbaharui dan memperkuat system hukum. Pengiriman para ahli hukum Amerika ini merupakan bagian yang tak terpisahkan dari agenda bantuan. Hal ini dapat dilihat secara nyata dari besarnya bantuan keuangan yang dianggarkan, dimana untuk Afrika misalnya diperkirakan sebesar US \$ 15 juta dan sebesar US \$ 5 juta. Biaya yang besar ini dikeluarkan karena ada anggapan bahwa modernisasi hukum pada negara-negara yang baru itu sangat diperlukan dan hukum yang modern itu diperlukan untuk mempromosikan pembangunan ekonomi.

Hal di atas didasari oleh pemikiran bahwa hukum yang modern itu akan memberi pengaruh pada pembangunan ekonomi, karena hukum yang modern itu memberikan fasilitas dan ruang pada perencanaan ekonomi sebab hukum yang modern itu sebagai sarana yang tepat untuk membangun masyarakat.

\section{Upaya Pemberdayaan Masyarakat Hukum Adat melalui Pembangunan Ekonomi Berbasis dan Kearifan Lokal.}

Persoalan paling mendasar yang ditunggu oleh masyarakat adalah pemberdayaan ekonomi, bukan hanya pertumbuhan. Paradigma pembangunan ekonomi selama era orde baru yang mengedepankan pertumbuhan ketimbang pemberdayaan dan pemerataan, terbukti telah melahirkan ketimpangan di banyak aspek. Puncaknya, ketika krisis ekonomi (dan moneter) melanda dunia, perekonomian kitapun terpuruk paling parah dibandingkan negara-negara tetangga.

Pembangunan ekonomi yang tidak mengakar kepada sendi-sendi kehidupan berbangsa terbukti telah gagal menjalankan perannya. Budaya-budaya lokal yang tercerabut dari akarnya atas nama pembangunan, juga telah nyata menyebabkan kita kehilangan identitas 
sebagai bangsa. Ke depan, para pemimpin di daerah harus menjalankan roda perekonomian dengan perspektif kearifan lokal (local wisdom).

Dari aspek bahasa, kearifan (wisdom) memiliki makna sebagai kemampuan seseorang dalam menggunakan akal pikirannya untuk menyikapi sesuatu kejadian, obyek atau situasi. Sedangkan lokal (local), merujuk pada ruang interaksi di mana peristiwa atau situasi tersebut terjadi. Secara substantif, kearifan lokal merupakan nilai dan norma yang berlaku dalam suatu masyarakat yang diyakini kebenarannya dan menjadi acuan dalam bertindak dan berperilaku sehari-hari..

Maman Djumantri menyatakan Secara generik dapat dikatakan bahwa "pembangunan adalah proses pengelolaan sumberdaya alam dan lingkungan untuk memenuhi kebutuhan manusia agar hidup sejahtera lahir dan batin". Terlepas dari bagaimana proses dan cara melaksanakannya, tujuan akhir pembangunan adalah kesejahteraan sosial (lahir maupun batin) bagi seluruh rakyat Indonesia. Jika pembangunan ditujukan untuk seluruh rakyat (bangsa) Indonesia, seyogya-nya menyertakan juga lapisan masyarakat tradisional atau masyarakat adat yang tersebar, terpencil dan marjinal. ${ }^{5}$

Guna memenuhi kebutuhan hidup manusia akan memanfaatkan apa yang tersedia di sekitarnya untuk itu manusia akan berusaha untuk beradaptasi agar melahirkan keseimbangan dan keteraturan dalam masyarakat. salah satunya adalah di berlakukannya sistem-sistem pengendalian sosial yang berupa norma \& hukum (adat) yang merupakan produk dari masyarakat tersebut. Dalam kelompok masyarakat tradisional indonesia atau dikenal dengan masyarakat adat dan norma/hukum yang

\footnotetext{
5 Djumantri,H.Maman. (2008). Ruang Untuk MasyarakatLokal Tradisional ( Masyarakat Adat) Semakin Terpinggirkan, Yogyakarta, h. 1.
}

berlaku di dalam masyarakat tradisional ini dikenal dengan hukum adat.

Menurut Van Apeldoorn perkataan adat semata-mata adalah peraturan tingkah laku, kaidah-kaidah yang meletakan kewajiban-kewajiban.

Peraturan tingkah laku yang dikatakan oleh Van Apeldoorn sebagai adat yang di anut oleh masyarakat desa atau disebut dengan nama lain diwariskan oleh nenek moyang atau datuk-datuk yang telah membentuk masyarakat desa itu untuk digunakan sebagai contoh kehidupan bagi keturunan-keturunan mereka.

Selanjutnya pudjosewojo melihat adat sebagai tingkah laku yang oleh dan dalam satu masyarakat (sudah, sedang, akan diadakan). ${ }^{8} \quad$ Peraturan tingkah laku yang menjadi adat istiadat dari suatu masyarakat adat ini dalam perkembanganya menjadi suatu norma hukum adat. Hukum adat untuk disebut hukum harus mengandung sanksi tertentu, baik berupa sanksi fisik maupun denda lainnya.

Menurut Soepomo, hukum adat adalah hukum yang hidup karena ia menjelmakan hukum yang nyata dari masyarakat, ia terus-menerus tumbuh dan berkembang seperti hidup itu sendiri dan hukum adat berurat akar pada kebudayaan teradisiona. 9 Dengan demikian hukum adat merupakan hukum yang hidup dan berkembang dalam masyarakat adat karena tidak dapat dipisahkan dari keberadaan dan dinamika masyarakat adat. Menurut Hazairin masyarakat hukum adat adalah kesatuan-kesatuan masyarakat yang

\footnotetext{
6. Apeldoorn, Van. (1978). Pengantar Ilmu Hukum, Jakarta: Pradya Paramita, h. 42.

7 Cooley, F.L. Altar and Thone in Center ar Molukas Societies a Dissertation Presented to the Faculity on the Depertemen of Religion, Yale University. h. 47.

8 Pujosewojo, Kusumadi. (1959). Pedoman pelajaran Tata Hukum Indonesia, Universitas Indonesia, h. 43

${ }^{9}$. Soepomo, Op Cit. h. 8
} 
mempunyai kelengkapan-kelengkapan untuk sanggup berdiri sendiri, yaitu mempunyai kesatuan hukum, kesatuan penguasa dan kesatuan lingkungan hidup berdasarkan hak bersama atas tanah dan air bagi semua anggotanya, bentuk hukum keluargannya (patrilineal, matrilineal, atau bilateral), semua anggotanya sama dalam hak dan kewajibannya. ${ }^{10}$

Salah satu peristiwa penting terkait dengan pengakuan dan penguatan masyarakat hukum adat berangkat dari hasil Earth Summit di Rio de Janeiro pada 1992 dengan dikeluarkannya Rio Declaration on Environment and Development (1992). Dalam Prinsip ke-22 dinyatakan bahwa masyarakat hukum adat mempunyai peranan penting dalam pengelolaan dan pembangunan lingkungan hidup karena pengetahuan dan praktik tradisional mereka. Oleh karenanya, negara harus mengenal dan mendukung penuh entitas, kebudayaan dan kepentingan mereka serta memberikan kesempatan untuk berpartisipasi aktif dalam pencapaian pembangunan yang berkelanjutan (sustainable development). Keberadaan masyarakat hukum adat diakui eksisktensinya oleh negara dalam pasal 18B ayat (2) UUD 1945 yang berbunyi "Negara mengakui dan menghormati kesatuan-kesatuan masyarakat hukum adat beserta hak-hak tradisionalnya". Selanjutnya ketentuan ini juga memberikan batasan sebagai syarat adanya pengakuan dan penghormatan yakni selama masyarakat hukum adat masih hidup dan sesuai dengan perkembangan masyarakat yang berlangsung secara terus menerus.

Kekayaan pengetahuan masyarakat adat di Indonesia sudah berkembang dalam jangka waktu yang panjang sejalan dengan perkembangan peradaban manusia. Proses perkembangan tersebut memunculkan banyak pengetahuan dan

\footnotetext{
${ }^{10}$ Soekanto, Soejono. (2012). Hukum Adat Indonesia, Jakarta: Rajawali Press, h. 93.
}

tata nilai tradisional yang dihasilkan dari proses adaptasi dengan lingkungannya. Sesuai dengan kebutuhan dasar manusia, salah satu bentuk pengetahuan tradisional yang berkembang adalah pengetahuan dalam pemanfaatan lahan,baik sebagai tempat tinggal maupun tempat untuk mencari atau memproduksi bahan makanannya. ${ }^{11}$

Dalam kaitannya dengan upaya pemberdayaan masyarakat hukum adat melalui pembangunan ekonomi berbasis norma hukum dan kearifan lokal, maka pemanfaatan, penggunaan dan pengelolaan sumberdaya alam dan kelestarian lingkungan, masyarakat adat ini dengan pengetahuan lokalnya (indigenus knowledge), dengan kekuatan memegang hukum adatnya, kemampuan spiritualnya, dan religi yang dianutnya, ternyata lebih arif dibandingkan masyarakat lainnya. ${ }^{12}$ Pengetahuan lokal yang dikenal sebagai kearifan lokal tumbuh dan berkembang didalam masyarakat sebagai pengetahuan yang di turunkan dari generasi kegenerasi sebagai bagian dari adaptasi terhadap lingkungannya.

Secara lebih spesifik, kearifan local dapat diartikan sebagai suatu pengetahuan lokal, yang unik yang berasal dari budaya atau masyarakat setempat, yang dapat dijadikan dasar pengambilan keputusan pada tingkat lokal dalam bidang pertanian, kesehatan, penyediaan makanan, pendidikan, pengelolaan sumberdaya alam dan beragam kegiatan lainnya di dalam komunitas-komunitas. Selanjutnya Wahyu juga menyatakan bahwa kemampuan memaknai kearifan lokal oleh individu, masyarakat dan pemerintah yang diwujudkan dalam cara berpikir,

11 .Kosmaryandi, N. (2005). Kajian Penggunaan Lahan Tradisional Minangkabau erdasarkan Kondisi Tanahnya (Study of Minangkabau Traditional Landuse Based on Its Soil ondition). Media Konservasi. Vol. X. No. 2. h. $77-81$.

12 Djumantri, H.Maman Op Cit. h. 2. 
gaya hidup dan kebijakan secara berkesinambungan dalam mengelola sumberdaya alam dan lingkungan dapat diharapkan untuk menghasilkan peningkatan berkehidupan yang berkualitas dalam masyarakat dan Negara. ${ }^{13}$ Pengakuan secara yuridis atas keberadaan masyarakat hukum adat dan kearifan lokalnya serta hak-haknya dapat dilihat dalam Pasal 1 ayat 30 Undang-Undang Nomor 32 Tahun 2009 menyatakan bahwa kearifan lokal adalah nilai-nilai luhur yang berlaku dalam tatanan hidup masyarakat untuk antara lain melindungi dan mengelola lingkungan hidup secara lestari. Selanjutnya pada Pasal 67 ayat (1b) Undang-Undang Nomor 41 Tahun 1999 Tentang Kehutanan menyatakan bahwa masyarakat hukum adat diakui keberadaanya berhak melakukan kegiatan pengelolaan hutan berdasarkan hukum adat yang berlaku dan tidak bertentangan dengan undang-undang. Pasal 6ayat (2) Undang-Undang Nomor 31 Tahun 2004 Tentang Perikanan menyebutkan bahwa pengelolaan perikanan untuk kepentingan penangkapan ikan dan pembudidayaan ikan harus mempertimbangkan peran serta masyarakat.Dalam pasal 61 ayat (1 dan 2) Undang-Undang Nomor 27 Tahun 2007 Tentang Pengelolaan Wilayah Pesisir dan Pulau-pulau Kecil, Pemerintah mengakui, menghormati dan melindungi hak-hak masyarakat adat, masyarakat tradisionaldan kearifan lokal atas wilayah pesisir dan pulau-pulau kecil yang telah dimanfaatkan secara turun temurun dijadikan acuan dalam pengelolaan wilayah pesisr dan pulau-pulau kecil yang berkelanjutan. Pengetahuan masyarakat adat dalam sistim pengelolaan sumber daya alam yang luar biasa (menunjukkan tingginya ilmu pengetahuan mereka) dan dekat sekali dengan alam. Maluku merupakan

13 Mukti, Abdul. (2010). Beberapa Kearifan Lokal Suku Dayak Dalam Pengelolaan Sumberdaya Alam, Malang: Brawijaya, h. 1 salah satu propinsi Indonesia yang secara geografisnya memiliki wilayah laut yang lebih luas dari wilayah darat. Dengan jumlah pulau mencapai 976 buah pulau dan secara administratif terbagi atas 8 (delapan) kabupaten kota. Dimana sebagaian besar penduduk maluku menyebar dan tinggal di pesisir sejumlah pulau besar dan kecil. Kehidupan masyarakat Maluku yang kaya akan sumber daya alam baik di laut maupun di darat masih berlaku hukum adat hal ini terlihat dari adanyaa kesatuan masyarakat yang teratur yang mempunyai penguasa dan men etap disuatu wilayah tertentu yang dikenal dengan wilayah petuanan (ulayat). Kesatuan hukum adat masyarakat ini sejak dahulu sangat berpengaruh dalam berbagai aspek, baik pemerintahan, ekonomi terutama pengelolaandan perlindungan lingkungan hidup, hal ini terlihat dengan masih sangat bergantungnya masyarakat adat malukupada ketersediaan lingkungan, kehidupan masyarakat yang masih bersifat komunal dan masih mempertahankan kearifan lokal yag didapatnya dari pengetahuan yang diturunkan secara turun temurun.

Dalam kenyataannya dengan pemberdayaan masyarakat hukum adat melalui pembangunan ekonomi berbasis norma hukum dan kearifan lokal, maka sistem pengelolaan lingkungan secara tradisonal terbukti mempunyai nilai penting dalam perlindungan dan pelestarian lingkungan, termasuk dalam konteks sosial dan pemberdayaan masyarakat hukum adat melalui pembangunan ekonomi berbasis khususnya bagi masyarakat adat maluku yang kehidupannya sangat bergantung pada hasil-hasil perikanan dan pertanian. dalam kaitannya dengan pemberdayaan masyarakat hukum adat melalui pembangunan ekonomi berbasis norma hukum dan kearifan lokal terutama dalam pemanfaatan, penggunaan dan 
pengelolaan sumber daya lingkungan dan perlindungan lingkungan, masyarakat adat ini dengan pengetahuan/ kearifan lokalnya , dengan kekuatan memegang hukum adatnya, kemampuan spiritualnya, dan religi yang dianutnya, ternyata lebih arif dibandingkan masyarakat lainnya.

Masyarakat adat maluku dengan kearifan lokalnya sebagai bagian dari struktur pemerintahan negara, harus diposisikan sebagai bagian integral dalam proses pembangunan. Artinya partisipasi aktif masyarakat adat harus direspons secara positif oleh pemerintah. Masyarakat adat harus diberikan kebebasan untuk berkreasi sesuai potensi yang dimiliki, sehingga ada keseimbangan. Kebijakan pembangunan harus terintegrasi dengan tetap berbasis pada masyarakat adat yang mempunyai hukum adat, sebagai bagian dari sistem hukum nasional yang patut diakui eksistensinya. Kehidupan sosial dan budaya masyarakat maluku yang tidak terlepas dari hukum adat digunakan dalam upaya pengelolaan sumber daya alam guna memenuhi kebutuhan hidupnya sekaligus sebagai upaya pelestarian atas sumber daya hayati dan ekosistemnya.

Salah satu bentuk pengelolaan dan perlindungan atas lingkungan hidup oleh masyarakat adat maluku sebgai contoh adalah sasi. Sasi merupakan praktik-praktik pengelolaan dan perlindungan sumber daya alam yang dilaksanakan masyarakat adat maluku dinilai selaras dengan prinsip pengelolaan lingkungan hidup yang lestari dan berkelanjutan. Sasi juga didukung oleh kebijakan adat sebagai bentuk pengetahuan lokal yang secara turun-temurun sudah mengatur bahwa pengelolaan dan pemanfaatan alam harus memperhatikan kelestarian sumber daya alam serta lingkungan. Sasi sebagai pranata adat mengandung kekuatan hukum yang mengikat bagi masyarakat adat tesebut karena dalam penyelangaraan sasi mengandung ketentuan yang mengatur tentang larangan serta kebolehan bagi masyarakat dalam pengelolaan lingkungan hidup dan perlindungannya. Keberlakuan hukum dalam sasi mengenal pembatasan wasktu berdasarkan jenis sumber daya alam yang diaturnya.

Di Maluku masyarakat adat yang tinggal pulau-pulau kecil maupun di wilayah pesisir memiliki sistem 'sasi' atau larangan memanen atau mengambil dari alam (di laut atau didarat) sumber daya alam tertentu untuk waktu tertentu. Sasi sebagai upaya perlindunganguna menjaga mutu dan populasi sumber daya alam hayati. Adanya larangan pengembilan hasil sebelum waktunya, maka akan terjadi peningkatan populasi sumber daya alam hayati. Penerapan sasi diterapkan pada sumber daya alam di laut maupun didarat, di darat sasi diberlakukan pada tanaman dan buah-huahan yang dilarang untuk di panen setiap waktu, ada waktu-waktu tertentu tanaman tersebut dilarang untuk di ambil dengan tujuan hasil yang di dapat lebih maksimal dan dapat memenuhi kebutuhan masyarakat adat tersebut. Larangan dalam hukum sasi mulai berlaku sejak adanya upacara adat "tutup sasi" dan berakhinya hukum sasi saat upacara "buka sasi " di lakukan. Dengan ditetapkannya sasi atas spesies dan di wilayah tertentu oleh Kewang maka siapapun tidak berhak untuk mengambil spesies tersebut. Ketentuan ini memungkinkan adanya pengembang-biakan dan membesarnya si ikan lompa, untuk kemudian di panen ketika sasi dibuka lagi. ${ }^{14}$

Lain lagi bentuk pengelolaan dan perlindungan lingkungan hidup Masyarakat Adat Aru (Maluku Tenggara), berperadaban yang ecocentrism, tercermin dalam eksploitasi

14 Moniaga, Sandra. (2002). Hak-hak Masyarakat Adat dan Masalah serta Kelestarian Lingkungan Hidup di Indonesia, Media Pemajuan Hak Asasi Manusia, No. 10/Tahun II/12 Juni Jakarta diakses pada http://www.huma.or.id 
sumberdaya pesisir dan laut sebagai pemberdayaan masyarakat hukum adat melalui pembangunan ekonomi mata-pencaharian utamanya dengan memanfaatkan pengetahuan dan kearifan lokal pada sebuah ekosistem pesisir dan kepulauan. Pada Musim Timur (Mei-Oktober) mereka bekerja di kebun membuat kanji dari sagu dan berburu, Pada Musim Barat (November-April) lebih terfokus pada sumberdaya laut seperti mengumpulkan Teripang dipesisir pantai yang sedang pasang ataupun berburu Hiu. Pengumpulan teripang oleh masyarakat adat Aru tidak mengunakan alat apapun tetapi memanfaatkan pengetahuan/kearaifan lokal (indigenous knowledge) mengenai kehidupan Tripang seperti habitat yang disukainya, bulan apa bereproduksi, pada cuaca bagaimana menampakkan diri dan sebagainya. Melalui pengetahuan lokal inilah komunitas lokal Aru mengorganisasikan kekuatannya mengelola sumberdaya alam yang satu ini secara lestari. Sebagai contoh: Di Musim Barat saat pasang naik merupakan saat yang tepat untuk "memanen"Tripang; tetapi dibatasi dari November sampai Maret karena Tripang (khususnya Tripang Putih dan Tripang Matahui) berproduksi pada bulan April. Masyarakat adat Aru sangat kuat memegang kepercayaan yang dianutnya yang berhubungan erat dengan mitologi, hal ini menjadi instrumen tangguh dalam menjaga kelestarian alam dan keberlanjutanya, karena alam dan seluruh isinya dianggap sebagi milik leluhurnya yang senantiasa memantau agar pengunaan sumber daya alam sehemat mungkin sekedar untuk memenuhi kebutuhan hidup dan memikirkan mereka yang akan hidup. Kepala adat sebagi mediator antara leluhur dan anak cucunya pada waktu-waktu tertentu akan melakukan dialog, hasil dialog tersebut berupa kesepakatan untuk hanya menagambil teripang yang berukuran besar dan ada masa larangan (restriction) untuk mengambil teripang atau yang dikenal dengan sasi teripang selama \pm 3 (tiga) tahun, hal ini dimaksud agar memberikan kesempatan pada alam untuk melakukan regenerasi. Jika hal ini dilanggar maka akan terjadi penyimpangan yang dimanifestasikan dengan bencana alam. ${ }^{15}$

Melihat bentuk pengelolaan dan perlindungan lingkungan hidup masyarakat adat Maluku dalam pemberdayaan masyarakat hukum adat dapat dikatakan bahwa tujuan utama dari sasi di Maluku khusunya Masyarakat Adat Aru (Maluku Tenggara) merupakan wujud dari kesadaran dan kearifan lokal masyarakat adat setempat dalam pengelolaan dan perlindungan serta pelestarian lingkungan hidup sebagai modal dasar bagi pemberdayaan masyarakat hukum adat melalui pembangunan ekonomi. Dengan adanya sasi warga masyarakat adat tidak mengelola sumberdaya alamnya secara sembarangan sehingga sumber daya alam yang ada dapat berdaya guna dan lestari demi kepentingan dan kesejahtraan masyarakat.

Keberadaan masyarakat adat sebagai bagian dari negara kesatuan republik Indonesia yang di akui hak-hak adat dan sistem hukumnya, termasuk sumber daya alam yang ada di wilayahnya. Untuk itu masyarakat adat perlu diberikan kesempatan untuk mengelola dan memanfaatkan suberdaya alam di wilayahnya sesuai dengn kearifan lokal yang dimilikinya. Sasi sebagai kearifan lokal masyarakat adat maluku merupakan modal dan model pengelolaan dan perlindungan lingkungan hidup di tingkat daerah terutama maluku dan nasional, dimana pembangunan sumber daya alam harus selaras, serasi, dan seimbang dengan fungsi lingkungan hidup. Sebagai konsekuensinya, kebijakan, rencana, dan/atau program pembangunan harus dijiwai oleh kewajiban melakukan pelestarian 
lingkungan hidup dan mewujudkan tujuan pembangunan pemberdayaan masyarakat hukum adat melalui pembangunan ekonomi secara berkelanjutan.

\section{PE N U T U P}

Indonesia sebagai Negara berkembang memiliki potensi yang luar biasa untuk menjadi Negara paling maju dan makmur di dunia. Potensi itu dapat kita lihat dari kekayaan alam yang berlimpah di beribu-ribu pulau yang tersebar di Nusantara. Potensi yang cukup besar ini akan lebih dan dapat memberi kontribusi bagi dunia jika didukung oleh sumber daya manusia yang handal. Dengan adanya regulasi hukum dalam kegiatan ekonomi dapat mencegah adanya tindakan sewenangwenangan dari pihak yang kuat terhadap pihak yang lemah. Dengan demikian diharapkan pembangunan ekonomi akan berjalan adil dan menunjang pembangunan ekonomi karena melalui hukum masyarakat diarahkan untuk melakukan atau tidak melakukan hal-hal tertentu untuk mencapai tujuan ekonomi yang diinginkan. Dalam kaitannya dengan upaya pemberdayaan masyarakat hukum adat melalui pembangunan ekonomi berbasis kearifan lokal, maka pemanfaatan, penggunaan dan pengelolaan sumberdaya alam dan kelestarian lingkungan, masyarakat adat ini dengan pengetahuan lokalnya (indigenus knowledge), dengan kekuatan memegang hukum adatnya, kemampuan spiritualnya, dan religi yang dianutnya, ternyata lebih arif dibandingkan masyarakat lainnya

\section{DAFTAR PUSTAKA}

Apeldoorn, Van. (1978). Pengantar Ilmu Hukum, Jakarta: Pradya Paramita.

Cooley, F.L. Altar and Thone in Center ar Molukas Societies a Dissertation Presented to the Faculity on the Depertemen of Religion, Yale
University.

Djumantri, H.Maman. (2008). Ruang

Untuk

MasyarakatLokal

Tradisional ( Masyarakat Adat )

Semakin

Terpinggirkan,

Yogyakarta.

Friedman, Lawrence M. (1977). Law and Society An Introduction, New Jersey: Prentice Hall Inc.

Koesnoe, Moch.(2000). Prinsip-prinsip Hukum Adat tentang Tanah, Surabaya: Ubhara Press.

Mubarak dan Hasyim, (2008). Buku Ajar II Manusia, Akhlak, Budi Pekerti dan Masyarakat, Universitas Indonesia.

Mukti, Abdul. (2010). Beberapa Kearifan Lokal Suku Dayak Dalam Pengelolaan Sumberdaya Alam, Malang: Brawijaya.

Pujosewojo, Kusumadi. (1959). Pedoman pelajaran Tata Hukum Indonesia, Universitas Indonesia.

Soepomo, Bab-Bab Tentang Hukum Adat. Jakarta: Pradnya Paramita.

Soekanto, Soejono. (2012). Hukum Adat Indonesia, Jakarta: Rajawali Press.

\section{Lain - Lain}

Kosmaryandi, N. (2005). Kajian Penggunaan Lahan Tradisional Minangkabau erdasarkan Kondisi Tanahnya (Study of Minangkabau Traditional Landuse Based on Its Soil ondition). Media Konservasi. Vol. X. No. 2.

Moniaga, Sandra. (2002). Hak-hak Masyarakat Adat dan Masalah serta Kelestarian Lingkungan Hidup di Indonesia, Media Pemajuan Hak Asasi Manusia, No. 10/Tahun II/12 Juni Jakarta diakses pada http://www.huma.or.id. 